\title{
Design, Syntheses and Antitumor Activities Evaluation of 1,5-diaryl Substituted Pyrazole Secnidazole Ester Derivatives
}

\section{Qing-Hu Teng}

Guilin University of Technology

\section{Gui-Xia Sun}

Guilin University of Technology

\section{Shu-Ying Luo}

Guilin University of Technology

kai wang ( $\sim$ kaiwang2011@yahoo.com )

Guilin University of Technology

\section{Fu-Pei Liang}

Guilin University of Technology

\section{Original Article}

Keywords: Drug hybridization principle, 1,5-Diaryl substituted pyrazole, Secnidazoles, Antitumor activities

Posted Date: February 9th, 2021

DOI: https://doi.org/10.21203/rs.3.rs-175570/v1

License: (9) This work is licensed under a Creative Commons Attribution 4.0 International License. Read Full License 


\title{
Design, syntheses and antitumor activities evaluation of 1,5-diaryl substituted pyrazole secnidazole ester derivatives
}

\author{
Qing-Hu Teng ${ }^{1} \cdot$ Gui-Xia Sun $^{1} \cdot$ Shu-Ying Luo $^{1} \cdot$ Kai Wang $^{1} \cdot$ Fu-Pei Liang ${ }^{1}$
}

\begin{abstract}
According to the drug hybridization principle, a series of novel 1,5-diaryl substituted pyrazole secnidazole ester derivatives (6aa-6gc) have been synthesized by the combinations of various 1,5-diarylpyrazole-3-carboxylic acids with secnidazole. The in vitro antitumor/cytotoxicities activities against tumor and normal cell lines, including NCI-H460 (lung tumor cell), MCG-803 (gastric tumor cell), Skov-3 (ovarian tumor cell), BEL-7404 (liver tumor cell) and HL-7702 (normal liver cell), have been evaluated using MTT assay. All compounds showed promising inhibitory activities against four tumor cell lines. The $\mathrm{IC}_{50}$ of $\mathbf{6 b c}$ against the BEL-7404 cell was $2.03 \mu \mathrm{M}$, and those of $6 \mathbf{f e}$ against the NCI-H460, MCG-803 and Skov-3 were 1.34, 0.14 and $0.87 \mu \mathrm{M}$, respectively. All these values were much lower than those of the cisplatin. Furthermore, $6 \mathbf{f c}$ and $\mathbf{6 b c}$ were also verified to be considerable safe for normal human liver cell, since the lower $\mathrm{IC}_{50}$ values than cisplatin. Based on these results, the cell cycle analysis, apoptosis ratio detection, and mitochondrial membrane potential assay of $\mathbf{6 f c}$ and $\mathbf{6 b c}$ were further performed aiming to investigate their inhibition mechanism of BEL-7404 cells. It is revealed that they have effectively inhibited the cell growth by arresting the BEL-7404 cells at S phase and induced apoptosis through the mitochondria-mediated pathway.
\end{abstract}

Keywords: Drug hybridization principle; 1,5-Diaryl substituted pyrazole; Secnidazoles; Antitumor activities

\section{Graphical Abstract}
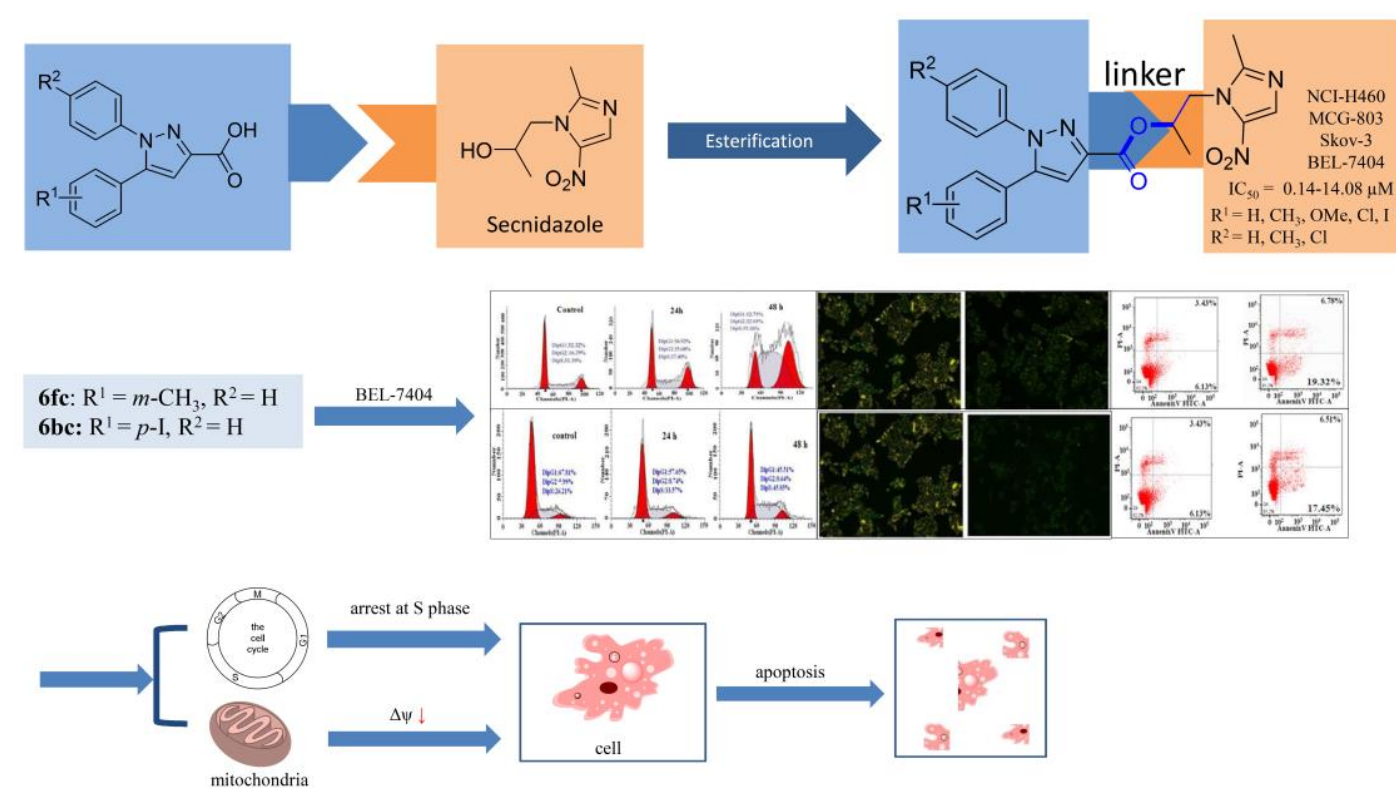
Supplementary information The online version contains

supplementary material available at https://doi.org/xxx

$\square$ Kai Wang

kaiwang2011@yahoo.com

$\square$ Fu-Pei Liang

fliangoffice@yahoo.com

${ }^{1}$ Guangxi Key Laboratory of Electrochemical and Magnetochemical Functional Materials, College of Chemistry and Bioengineering, Guilin University of Technology, Guilin, 541004, China.

\section{Introduction}

As one type of the core frameworks in various natural products and medicines, nitrogen-containing heterocycles have played important roles in drug design and development. ${ }^{1}$ The pyrazole is just one of such species. They have shown extensive bioactivities, ${ }^{2}$ such as anti-tumor, ${ }^{3}$ antimicrobial, ${ }^{4}$ antifungal, ${ }^{5}$ hypoglycemic, ${ }^{6}$ anti-inflammatory, ${ }^{7}$ analgesic, ${ }^{8}$ against oxidative stress and diabetes, ${ }^{9}$ and various enzyme inhibiting activities, ${ }^{10}$ etc. In particular, promising potentials against the malignant tumor have been demonstrated in some of modified pyrazole derivatives when they were grafted with other active groups according to the drug hybridization principle. For instances, the methyl sulfone pyrazole derivatives, which could behavior as the bifunctional conjugates with potent inhibitory activity towards cyclooxygenase (COX) and histone deacetylase (HDAC), could arrest the cell cycle progression of androgen dependent prostate tumor cell line ( $\mathrm{LNCaP})$ in the $\mathrm{S}$ - and G0/G1 phases. ${ }^{11}$ Several hybridization of pyrazoles and substituted coumarins/morpholines groups have also found to be potent dual COX-2/5-LOX inhibitors and antitumor agents. Their lowest $\mathrm{IC}_{50}$ have reached to $0.16 \mu \mathrm{M} .^{12}$ These results suggested that more extensive and prominent anti-tumor activities could be expected when such pyrazole parents were hybridized with other novel active groups.

As a next-generation of 5-nitroimidazole, secnidazole has been approved for a single-dose ( $2 \mathrm{~g})$ treatment of bacterial vaginosis (BV), as well as commercially available for more than three decades in 31 countries. $^{13}$ Moreover, secnidazole can also undergo a bioreduction of the nitro group to generate toxic reactive oxygen species (ROS), which leading to DNA helix damage, disruption of bacterial protein synthesis and replication, and ultimately, cell death. ${ }^{14}$ On this basis, special attention have been paid to its structural modifications. Several secnidazole derivatives, including esters and metal-complexes, have been reported as potential drug in tumor growth inhibition. ${ }^{15}$ It should be noted that, its derivatives that stem from the combination of pyrazoles with secnidazoles was rarely investigated yet. Up to now, only series of compounds synthesized form the coupling reaction of 4-(1-acetyl-3-phenyl-4,5-dihydro- $1 H$-pyrazol-5-yl)benzoic acid with secnidazole has been developed. And it is gratifying that these compounds have been determined to bear excellent antitumor activities. $^{16}$

In recent years, our group have been interested in the development of new methodologies for the syntheses of new nitrogen heterocycles molecules, as well as the searching of novel antitumor targeted drug candidates. ${ }^{17}$ Based on these works and combined with excellent antitumor potentials of the pyrazole and secnidazole groups (Scheme 1), we have designed and synthesized various 1,5-diaryl substituted pyrazole secnidazole ester derivatives. The antitumor activities of all obtained compounds have been evaluated using MTT assay. Several compounds have been found to bear much higher inhibiting activities against most of selected tumor cells than the cisplatin. Furthermore, they were also verified to be much safer for normal human liver cell than the cisplatin. In order to reveal their inhibition mechanism, the cell cycle analysis, apoptosis ratio detection, and mitochondrial membrane potential assay of selected compounds were also investigated.

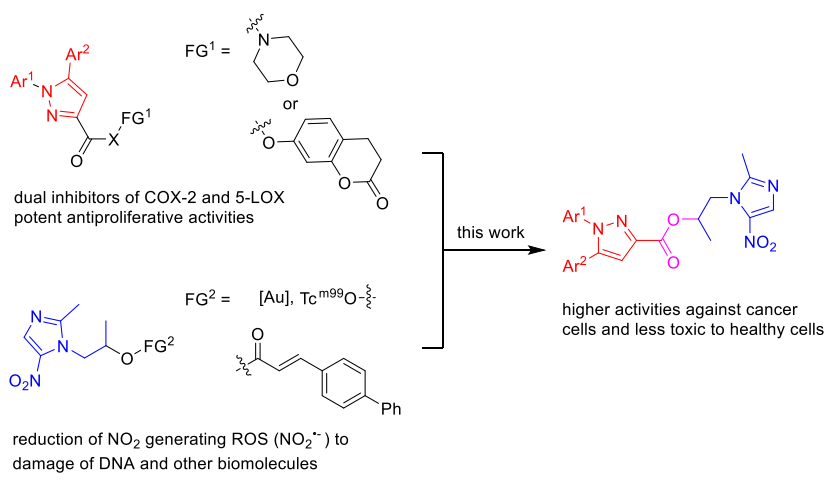

Scheme 1. Design philosophy of pyrazole secnidazole derivatives as antitumor agents.

\section{Results and discussion}

\section{Chemistry}

The syntheses of targeted compounds $\mathbf{6}$ are illustrated in Scheme 2. Their structural diversity stem from precursor compounds of 1,5-diaryl substituted $1 \mathrm{H}$-pyrazole-3carboxylic acid (5), in which various substituted benzene moieties have been introduced into the 1 - and 5-positions of pyrazole moieties according to previously reported mature method. ${ }^{3,12 \mathrm{~b}}$ Originally, methyl (Z)-2-hydroxy-4-oxo-4-phenylbut-2-enoate (2) were synthesized from substituted acetophenones (1) and dimethyl oxalate (DMO) through aldol condensation and Vilsmeier-Haack reaction. The reaction of $\mathbf{2}$ with para-substituted phenylhydrazines (3) afforded methyl 1,5-diphenyl-1 $H$-pyrazole-3-carboxylates (4) via an 
intermolecular cyclization mechanism. Various 1,5-diphenyl-1 $H$-pyrazole-3-carboxylic acid (5) were subsequently synthesized through successively implemented hydrolysis and acidification processes of $\mathbf{4}$. Finally, secnidazole active groups were introduced by simple esterification reactions, which yielded target compounds 1-(2-methyl-5-nitro-1H-imidazol-1-yl)propan-2-yl1,5-diphenyl-1H-pyrazole-3-carboxylate (6) in moderate to good yields.

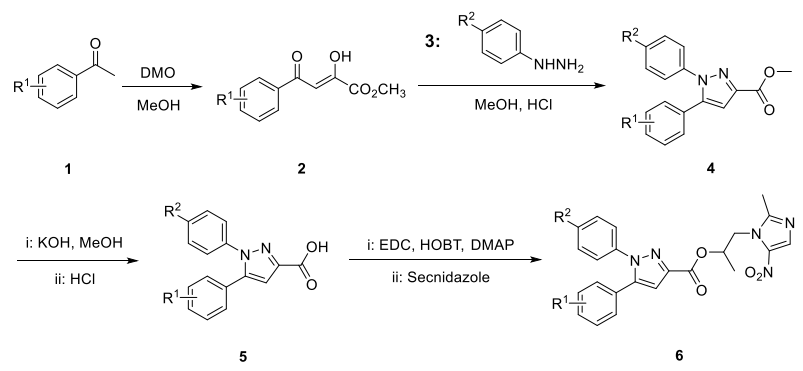

Scheme 2. Synthesis route of compounds 6.

The molecular structures and yields (\%) of these targeted compounds were summarized in Table 1. All targeted compounds were first reported and structurally characterized by ${ }^{1} \mathrm{H}$ NMR spectroscopy, ${ }^{13} \mathrm{C}$ NMR spectroscopy and ESI-MS. Taking 6aa as the example, its ${ }^{1} \mathrm{H}$ NMR spectrum showed a doublet of Me proton of propane at N1-secnidazole at $\delta 1.44(\mathrm{~d}, J=6.1 \mathrm{~Hz}, 3 \mathrm{H})$, three singlets of $\mathrm{Me}$ protons at para-5-phenyl, para-1-phenyl, and C2 of secnidazole appeared at $\delta 2.29$ $(\mathrm{s}, 3 \mathrm{H}), 2.35(\mathrm{~s}, 3 \mathrm{H}), 2.55(\mathrm{~s}, 3 \mathrm{H})$, respectively. The methylene $\left(\mathrm{CH}_{2}\right)$ protons of propane at N1-imidazole showed a multiplet at $\delta 4.54(\mathrm{~m}, 1 \mathrm{H})$, and a doublet at $\delta$ 4.69 (d, $J=14.1 \mathrm{~Hz}, 1 \mathrm{H})$, respectively. There was a broad singlet of methylene $(\mathrm{CH})$ proton of propane at N1-imidazole at $\delta 5.45(\mathrm{br}, 1 \mathrm{H})$. The protons of parazole and imidazole ring displayed at $\delta 6.96(\mathrm{~s}, 1 \mathrm{H})$ and $8.02(\mathrm{~s}$, $1 \mathrm{H})$ as singlets, respectively. The protons of 1, 5-diphenyl showed a multiplet at $\delta 7.11-7.19(\mathrm{~m}, 6 \mathrm{H})$, and a doublet at $\delta 7.26(\mathrm{~d}, J=7.8,2 \mathrm{H})$. Nearly similar patterns were noticed in ${ }^{1} \mathrm{H}$ and ${ }^{13} \mathrm{C}$ NMR spectra of all the compounds (6aa-6gc). The HRMS (ESI) of compounds (6aa-6gc) showed characteristic $[\mathrm{M}+\mathrm{H}]^{+}$corresponding peaks equivalent to their molecular formulae. Relevant spectral data is furnished in supporting information.

Table 1. Molecular structures and the yields of compounds 6aa-6gc.

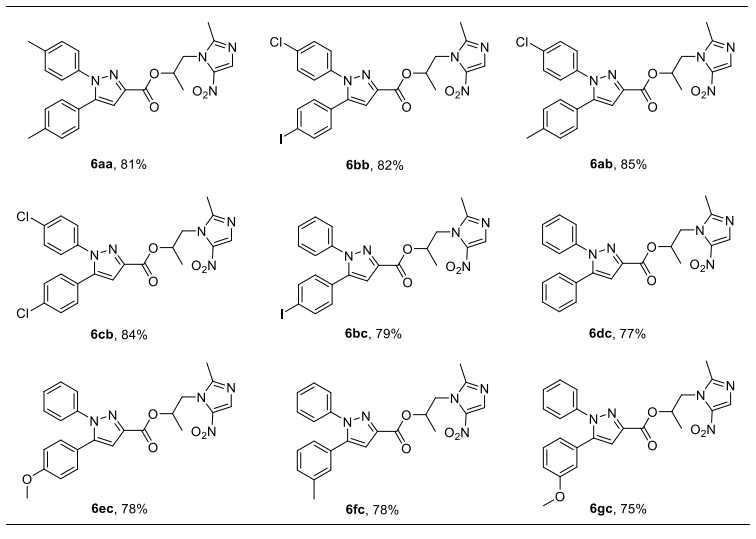

\section{Antiproliferation assays and MTT assays}

The antiproliferative effects of all targeted compounds were evaluated against four human tumor cell lines and a normal cell line using MTT assay. These cell lines include human lung tumor cell NCI-H460, human gastric tumor cell MCG-803, human ovarian tumor cell Skov-3, human liver tumor cell BEL-7404, and normal liver cell HL-7702. Cisplatin, a well-known marketed antitumor drug, was employed as the positive control in the MTT assay. As shown in Table 2, all compounds exhibited potent inhibitory activity against four tumor cells of NCI-H460, MCG-803, Skov-3, and BEL-7404. The IC 50 values of all compounds against four tumor cells range from 0.14 to $14.08 \mu \mathrm{M}$. Obviously, these values were all much lower than the corresponding $\mathrm{IC}_{50}$ values of the cisplatin. Among these, 6fc showed the highest inhibiting effects on tumor cell lines of NCI-H460, MCG-803, and Skov-3, with the $\mathrm{IC}_{50}$ values of $1.34,0.14$, and $0.87 \mu \mathrm{M}$, respectively. While for BEL-7404 tumor cell lines, the 6bc possessed the most significant inhibiting activity, whose $\mathrm{IC}_{50}$ value was determined to be $2.03 \mu \mathrm{M}$. It should be noted that the $\mathrm{IC}_{50}$ values of $\mathbf{6} \mathbf{f c}$ and $\mathbf{6 b c}$ against the human normal liver cell HL-7702 were 5.77 and 8.97 $\mu \mathrm{M}$, respectively, all of which were closed to that of the cisplatin $(7.93 \mu \mathrm{M})$. This meant that both of them displayed comparable cytotoxic activities as the cisplatin.

Table 2. $\mathrm{IC}_{50}(\mu \mathrm{M})$ values of compounds 6aa-6ge against four tumor cell lines and a normal cell line. ${ }^{\mathrm{a}}$

\begin{tabular}{cccccc} 
Compound & NCI-H460 & MCG-803 & Skov-3 & BEL-7404 & HL-7702 \\
\hline $\mathbf{6 a a}$ & 14.08 & 0.32 & 7.34 & 4.56 & 8.46 \\
$\mathbf{6 b b}$ & 2.43 & 1.27 & 2.67 & 2.78 & 6.25 \\
$\mathbf{6 a b}$ & 4.68 & 0.68 & 1.47 & 6.45 & $\underline{\mathbf{5 . 3 4}}$ \\
$\mathbf{6 c b}$ & 6.42 & 1.05 & 3.38 & 7.66 & 7.81 \\
$\mathbf{6 b c}$ & 7.88 & 2.47 & 6.59 & $\underline{\mathbf{2 . 0 3}}$ & 5.77 \\
$\mathbf{6 d c}$ & 6.67 & 3.52 & 3.17 & 8.59 & 11.76
\end{tabular}




\begin{tabular}{cccccc}
\hline $\mathbf{6 e c}$ & 3.85 & 0.79 & 9.69 & 4.65 & 16.52 \\
$\mathbf{6 f c}$ & $\underline{\mathbf{1 . 3 4}}$ & $\underline{\mathbf{0 . 1 4}}$ & $\underline{\mathbf{0 . 8 7}}$ & 5.28 & 8.97 \\
$\mathbf{6 g c}$ & 3.54 & 1.86 & 10.37 & 11.24 & 57.78 \\
Cisplatin & 48.52 & 4.19 & 84.21 & 24.87 & 7.93 \\
\hline
\end{tabular}

${ }^{a} \mathrm{IC}_{50}$ : Concentration inhibits $50 \%$ of cell growth. Data are shown as the mean of three independent experiments run in triplicate.

The above results confirmed the validity of our design, the hybridization of pyrazole and secnidazole could result in compounds with excellent antitumor activities. In order to further probe antitumor mechanism of targeted compounds, compounds 6fc and 6bc were selected to determine the cell cycle analysis, apoptosis ratio detection, and mitochondrial membrane potential assay using BEL-7404 cell line.

\section{Apoptosis study by flow cytometry and confocal microscopy}

In order to verify whether the compounds induced cell death was caused by apoptosis or necrosis, the interactions of BEL-7404 cells with 6fc or 6bc was investigated by an annexin V-FITC/propidium iodide assay using flow cytometry. Considering the fact that in apoptosis process the phosphatidylserine (PS) exposure usually occurs before the loss of plasma membrane integrity, the presence of annexin $\mathrm{V}^{+} / \mathrm{PI}^{-}$cells was regarded as an indicator of apoptosis. As shown in Fig. 1, the presence of both $\mathbf{6 f c}$ and $\mathbf{6 b c}$ have led to the obvious increasing of the population of annexin $\mathrm{V}^{+} / \mathrm{PI}^{-}$cells $(26.1 \%$ for 6fe and $23.96 \%$ for 6bc) in comparison with that of control $(9.56 \%)$. These results suggested that apoptotic death of BEL-7404 cells was induced by two tested compounds.
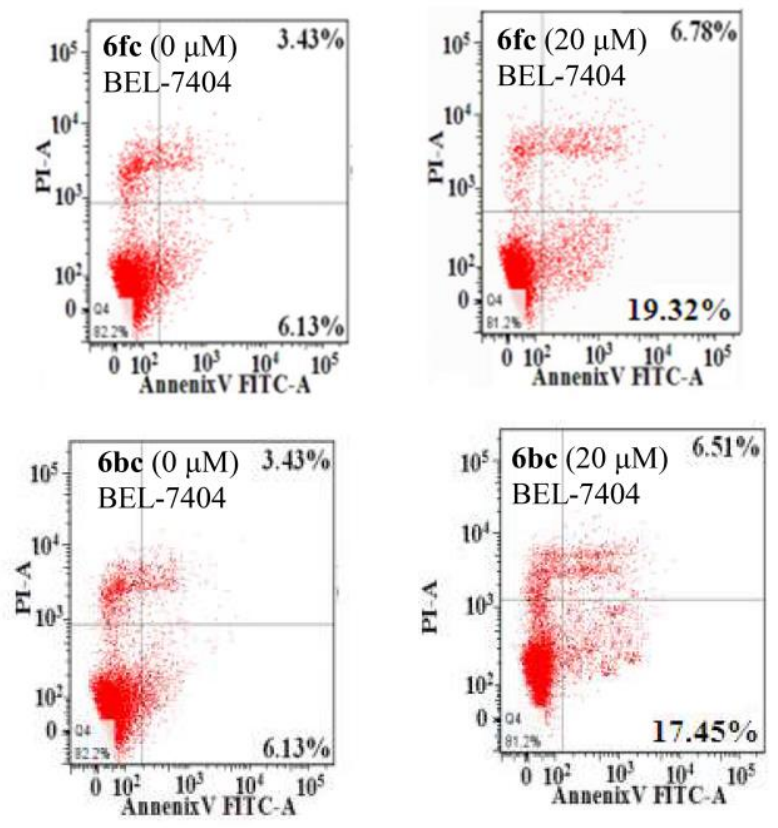

Fig. 1 Annexin-V/propidium iodide assay of the BEL-7404 cells treated with $6 \mathbf{f c}$ and 6 bc $(20.0 \mu \mathrm{M})$.

\section{Cell cycle arrest}

Meanwhile, the flow cytometry analysis was also employed to determine the apoptosis ration of BEL-7404 cell line induced by $\mathbf{6 f} \mathbf{c}$ and $\mathbf{6 b c}$, thereby the relationships between inhibiting activities of above compounds and the cell cycle arrest of corresponding BEL-7404 cells could be illustrated. In this assay, the BEL-7404 cells were treated with $6 \mathbf{f c}$ and $\mathbf{6 b c}$ at their $\mathrm{IC}_{50}$ concentrations, following which the cell cycle phase was assayed by evaluating the DNA content of cells stained with propidium iodide. As shown in Fig. 2, with the extending of treating time, compound $\mathbf{6 f c}$ has caused increased accumulation of BEL-7404 cells in the S phases but a decrease in the accumulation in the G1 phase. The percentage of $\mathrm{S}$ phase for control, at 24 and $48 \mathrm{~h}$ were $31.39,37.40$ and $55.26 \%$, respectively. As for the cells treated with $\mathbf{6 b c}$, the percentage of G1 phase among them also decreased along with the treating time extending. And the percentage of $\mathrm{S}$ phase also underwent a substantially rising. It has increased from $26.21 \%$ for control to the $33.57 \%$ at $24 \mathrm{~h}$, and finally reached to the $45.85 \%$ at $48 \mathrm{~h}$. Therefore, the $\mathbf{6 f c}$ and $\mathbf{6 b c}$ could arrest cell cycle of BEL-7404 cells at S phase. And based on these results it could be concluded that DNA may be one of the possible intracellular targets for $\mathbf{6 f c}$ or $\mathbf{6 b c}$, because most DNA replication occurs within this $S$ stage. 

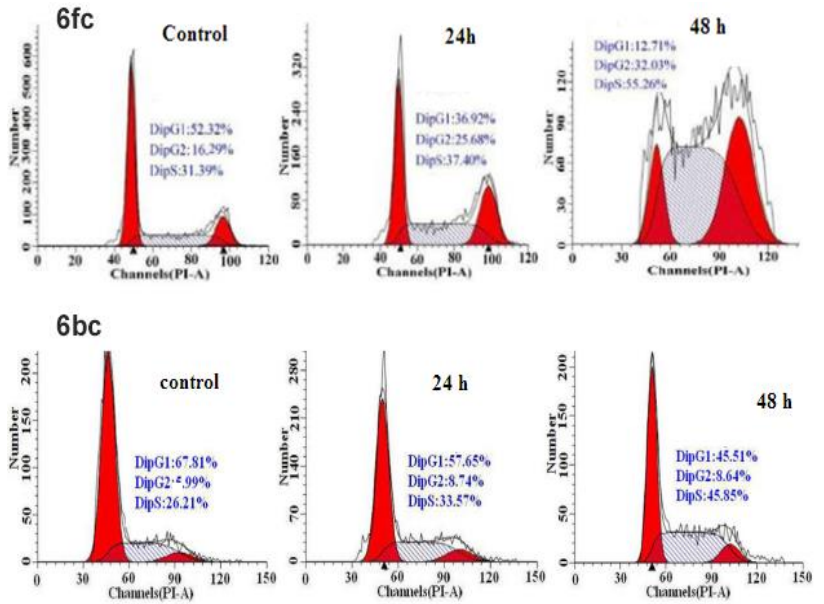

Fig. 2. Cell cycle analysis by flow cytometry for BEL-7404 cells treated with $\mathbf{6 f c}$ and $\mathbf{6 b c}$

\section{Detection of mitochondrial membrane potential}

It is known that mitochondria play significant roles in the process of cell apoptosis. They could act as a point of integration for apoptotic signals, which stem from both the extrinsic and intrinsic apoptotic pathways. Particularly, the loss of mitochondrial membrane potential (MMP, $\left.\Delta \Psi_{\mathrm{m}}\right)$ is involved in apoptotic cell death due to the cytotoxicity of the antitumor drugs. Because of this, it is regarded as an important indicator of mitochondrial dysfunction. To investigate these roles of mitochondria in BEL-7404 apoptosis induced by $6 \mathbf{6 c}$ or $\mathbf{6 b c}$, the change of the mitochondrial membrane potential was evaluated. From Fig. 3 it could be observed that the BEL-7404 cells were obviously changed into green by treating with compounds $6 \mathbf{f c}$ and $\mathbf{6 b c}$ in the concentration of $20 \mu \mathrm{M}$, which indicated that the MMP was declined comparing with the control (Fig. 3.). That meant the mitochondrial-mediated pathways were involved in the apoptosis of BEL-7404 cells induced by $6 \mathbf{f c}$ and $\mathbf{6 b c}$. (a) control

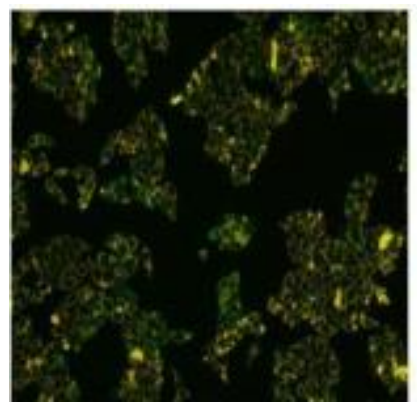

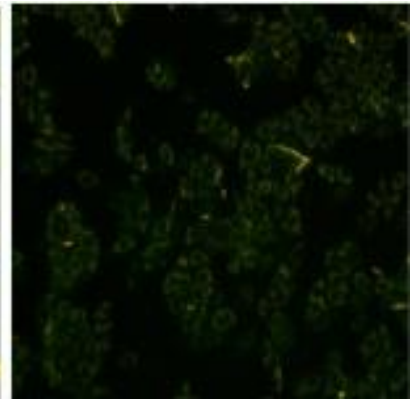

(b) 6 fc $(20 \mu \mathrm{M})$

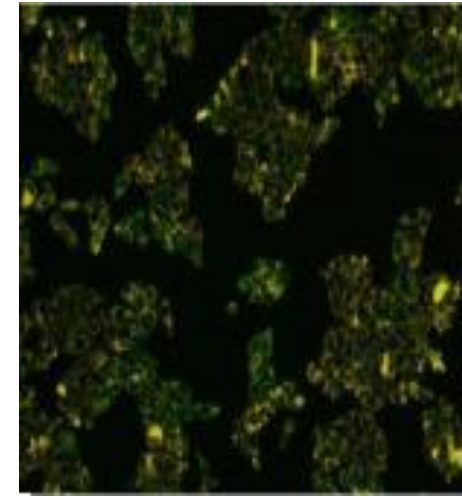

(c) control

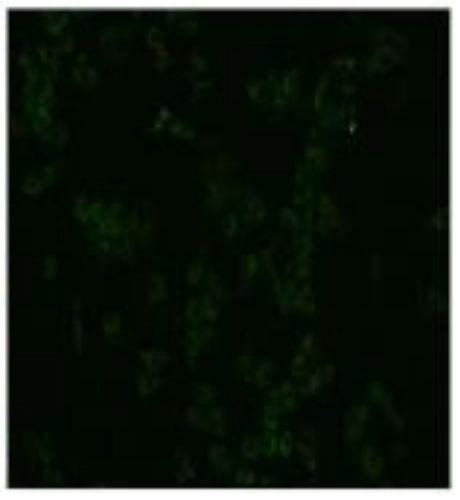

(d) 6 bc $(20 \mu \mathrm{M})$

\section{Conclusion}

In summary, nine novel hybrid compounds containing both diaryl substituted pyrazole and secnidazole groups have been designed and synthesized. They have been determined to showed potent in vitro inhibiting activities against selected four human tumor cell lines, which were all superior to those of the cisplatin. Among them, compound 6fc displayed the most significant inhibiting activities against human tumor cell lines of NCI-H460, MCG-803 and Skov-3. While for BEL-7404 cell, compound $6 \mathbf{b c}$ did the best. Further studies revealed the possible antitumor mechanism of $\mathbf{6 f c}$ and $\mathbf{6 b c}$. Both of them could arrest the BEL-7404 cell cycle at S phase, and induced apoptosis of BEL-7404 cells through mitochondrial-mediated pathway.

\section{Experimental section}

\section{Synthesis and characterization of 1-(2-methyl-5-nitro-1H-imidazol-1-yl)propan -2-yl 1,5-diphenyl-1H-pyrazole-3-carboxylate (6) Conventional procedure:}

\section{Synthesis of compounds 2}

The reaction mixture of $\mathbf{1}(8 \mathrm{mmol})$, dimethyl oxalate (16 mmol), and dry $\mathrm{CH}_{3} \mathrm{OH}(20 \mathrm{~mL})$ was slowly added into the mixture of $\mathrm{CH}_{3} \mathrm{ONa} / \mathrm{CH}_{3} \mathrm{OH}(16 \mathrm{mmol} / 5 \mathrm{~mL})$. The reaction mixture was stirred at reflux for $5 \mathrm{~h}$, and monitored periodically by TLC. Upon completion, the reaction mixture was cooled to room temperature and poured into water $(50 \mathrm{~mL})$. Then, the mixture was stirred and added $\mathrm{HCl}(1 \mathrm{M})$ until $\mathrm{pH}=3-4$. After neutralization, the mixture was extracted with ethyl acetate $(3 \times 100 \mathrm{~mL})$. The combined organic layers were washed with water and brine, dried over $\mathrm{NaSO}_{4}$ and filtered. The solvent was removed under vacuum. The residue was purified by flash column chromatography to afford $\mathbf{2}$.

\section{Synthesis of compounds 4}

The diluted $\mathrm{HCl}(1 \mathrm{~mL})$ was added into the reaction mixture of 2 (1 mmol), phenylhydrazines 3 (2 mmol), and dry $\mathrm{CH}_{3} \mathrm{OH}(12 \mathrm{~mL})$. The reaction mixture was reflux for 
$6 \mathrm{~h}$, and monitored periodically by TLC. Upon completion, the reaction mixture was cooled to room temperature and extracted with ethyl acetate $(3 \times 20 \mathrm{~mL})$. The combined organic layers were washed with water and brine, dried over $\mathrm{NaSO}_{4}$ and filtered. The solvent was removed under vacuum. The residue was purified by flash column chromatography to afford 4 .

\section{Synthesis of compounds 5}

$\mathrm{H}_{2} \mathrm{O}(1 \mathrm{~mL})$ was slowly added into the reaction mixture of 4 (0.5 mmol), $\mathrm{KOH}(1.75 \mathrm{mmol})$ and $\mathrm{CH}_{3} \mathrm{OH}(10 \mathrm{~mL})$. The mixture was reflux for $2 \mathrm{~h}$, and monitored periodically by TLC. Upon completion, the reaction mixture was cooled to room temperature and poured into $\mathrm{H}_{2} \mathrm{O}(15 \mathrm{~mL})$. Then, $\mathrm{HCl}(1 \mathrm{M})$ was added into the reaction mixture until $\mathrm{pH}=3-4$, followed by extracted with ethyl acetate $(3 \times 20 \mathrm{~mL})$. The combined organic layers were washed with water and brine, dried over $\mathrm{NaSO}_{4}$ and filtered. The solvent was removed under vacuum. The residue was purified by flash column chromatography to afford $\mathbf{5}$.

\section{Synthesis of compounds 6}

The reaction mixture of 5 ( 0.4 mmol $)$, 1-(3-dimethylaminopropyl)-3-ethylcarbodiimide hydrochloride (EDC, $0.48 \quad \mathrm{mmol}$ ), 1-Hydroxybenzotriazole hydrate (HOBt, $0.48 \mathrm{mmol}$ ), 4-dimethylaminopyridine (DMAP, $0.2 \mathrm{mmol}$ ), and DCE $(10 \mathrm{~mL})$ was stirred at $45^{\circ} \mathrm{C}$ for $0.5 \mathrm{~h}$. Then, sycnidazole $(0.52 \mathrm{mmol})$ was added into the reaction mixture and heated to reflux overnight. Upon completion, the reaction mixture was cooled to room temperature and extracted with DCM $(3 \times 20 \mathrm{~mL})$. The combined organic layers were washed with water and brine, dried over $\mathrm{NaSO}_{4}$ and filtered. The solvent was removed under vacuum. The residue was purified by flash column chromatography or recrystallized in $\mathrm{EtOH}$ to afford 6.

\section{Characterization of the compounds}

1-(2-Methyl-5-nitro-1H-imidazol-1-yl)propan-2-yl-1,5-di -p-tolyl-1H-pyrazole-3-carboxylate (6aa): yellow solid, mp: $171-172{ }^{\circ} \mathrm{C} ;{ }^{1} \mathrm{H}$ NMR (500 MHz, DMSO): $\delta=1.44$ $(\mathrm{d}, J=6.1 \mathrm{~Hz}, 3 \mathrm{H}), 2.29(\mathrm{~s}, 3 \mathrm{H}), 2.35(\mathrm{~s}, 3 \mathrm{H}), 2.55(\mathrm{~s}$, $3 \mathrm{H}), 4.54(\mathrm{~m}, 1 \mathrm{H}), 4.69(\mathrm{~d}, J=14.1 \mathrm{~Hz}, 1 \mathrm{H}), 5.45$ (br, $1 \mathrm{H}), 6.96(\mathrm{~s}, 1 \mathrm{H}), 7.11-7.19(\mathrm{~m}, 6 \mathrm{H}), 7.26(\mathrm{~d}, J=7.8,2 \mathrm{H})$, $8.02(\mathrm{~s}, 1 \mathrm{H}) \mathrm{ppm} ;{ }^{13} \mathrm{C} \mathrm{NMR}(125 \mathrm{MHz}, \mathrm{DMSO}): \delta=$ $14.58,17.75,21.12,21.23,50.01,70.11,109.66,125.78$, $126.45,128.93,129.70,130.14,133.67,137.26,138.76$, 138.94, 142.91, 144.90, 152.37, 161.13 ppm. $\mathrm{m} / z$ (MS): calcd for $\mathrm{C}_{25} \mathrm{H}_{26} \mathrm{~N}_{5} \mathrm{O}_{4}[\mathrm{M}+\mathrm{H}]^{+} 460.20$, found 460.25 .

1-(2-Methyl-5-nitro-1H-imidazol-1-yl)propan-2-yl-1-(4-c hlorophenyl)-5-(4-iodophenyl)-1H-pyrazole-1-(2-Methyl5-nitro-1H-imidazol-1-yl)propan-2-yl-1-(4-chlorophenyl) -5-(p-tolyl)-1H-pyrazole-3- carboxylate (6ab): yellow solid, mp: $169-171{ }^{\circ} \mathrm{C} ;{ }^{1} \mathrm{H}$ NMR (500 MHz, DMSO): $\delta=$ $1.44(\mathrm{~d}, J=6.4 \mathrm{~Hz}, 3 \mathrm{H}), 2.30$ (s, 3H), 2.55 (s, 3H), 4.55 (dd, $J=15.0,9.7 \mathrm{~Hz}, 1 \mathrm{H}), 4.69(\mathrm{dd}, J=15.0,2.7 \mathrm{~Hz}, 1 \mathrm{H})$, 5.45 (ddd, $J=9.4,6.4,2.8 \mathrm{~Hz}, 1 \mathrm{H}), 6.99(\mathrm{~s}, 1 \mathrm{H}), 7.14(\mathrm{~d}$, $J=8.2,2 \mathrm{H}), 7.20(\mathrm{~d}, J=8.1,2 \mathrm{H}), 7.34(\mathrm{~m}, 2 \mathrm{H}), 7.54$ (m, 2H), 8.02 (s, 1H) ppm; ${ }^{13} \mathrm{C} \mathrm{NMR} \mathrm{(125} \mathrm{MHz,} \mathrm{DMSO):} \delta=$ $14.58,17.74,19.91,21.26,48.48,70.24,80.47,109.99$, $126.15,127.70,129.05,129.78,129.82,133.67,139.20$, $141.38,143.39,145.16,148.84,152.36,156.64,161.01$ ppm. $m / z(\mathrm{MS})$ : calcd for $\mathrm{C}_{24} \mathrm{H}_{23} \mathrm{ClN}_{5} \mathrm{O}_{4}[\mathrm{M}+\mathrm{H}]^{+} 480.14$ found 480.20 .

1-(2-Methyl-5-nitro-1H-imidazol-1-yl)propan-2-yl-1-(4-c hlorophenyl)-5-(4-iodophenyl)-1H-3-carboxylate (6bb): yellow solid, mp: $156-158{ }^{\circ} \mathrm{C}$; ${ }^{1} \mathrm{H}$ NMR (500 MHz, DMSO): $\delta=1.44$ (d, $J=6.4 \mathrm{~Hz}, 3 \mathrm{H}), 2.54(\mathrm{~s}, 3 \mathrm{H}), 4.54$ $(\mathrm{dd}, J=15.0,9.7 \mathrm{~Hz}, 1 \mathrm{H}), 4.69(\mathrm{dd}, J=15.0,2.7 \mathrm{~Hz}, 1 \mathrm{H})$, 5.45 (ddd, $J=9.4,6.4,2.8 \mathrm{~Hz}, 1 \mathrm{H}), 7.05(\mathrm{~s}, 1 \mathrm{H}), 7.07$ (d, $J=1.2,2 \mathrm{H}), 7.36(\mathrm{~d}, J=8.7,2 \mathrm{H}), 7.56(\mathrm{~d}, J=8.7,2 \mathrm{H})$, $7.77(\mathrm{~d}, J=8.4,2 \mathrm{H}), 8.02(\mathrm{~s}, 1 \mathrm{H}) \mathrm{ppm} ;{ }^{13} \mathrm{C} \mathrm{NMR}(125$ $\mathrm{MHz}, \mathrm{DMSO}): \delta=14.60,17.73,67.70,70.31,96.60$, $110.45,117.46,127.72,129.88,131.11,131.15,133.78$, 138.03, 138.13, 143.48, 143.64, 144.15, 155.17, 160.89 ppm. $m / z$ (MS): calcd for $\mathrm{C}_{23} \mathrm{H}_{20} \mathrm{ClIN}_{5} \mathrm{O}_{4}[\mathrm{M}+\mathrm{H}]^{+}$592.02, found 592.10

1-(2-Methyl-5-nitro-1H-imidazol-1-yl)propan-2-yl-1,5-bi s(4-chlorophenyl)-1H-pyrazole-3-carboxylate (6cb) : yellow solid, mp: $224-226{ }^{\circ} \mathrm{C}$; ${ }^{1} \mathrm{H}$ NMR $(500 \mathrm{MHz}$, DMSO): $\delta=1.44$ (d, $J=6.4 \mathrm{~Hz}, 3 \mathrm{H}), 2.55(\mathrm{~s}, 3 \mathrm{H}), 4.54$ (dd, $J=15.0,9.7 \mathrm{~Hz}, 1 \mathrm{H}), 4.69$ (dd, $J=15.0,2.6 \mathrm{~Hz}, 1 \mathrm{H})$, $5.46(\mathrm{ddd}, J=9.4,6.4,2.8 \mathrm{~Hz}, 1 \mathrm{H}), 7.08(\mathrm{~s}, 1 \mathrm{H})$, 7.26-7.31 (m, 2H), 7.33-7.38 (m, 2H), 7.44-7.50 (m, 2H), 7.53-7.60 (m, 2H), $8.02(\mathrm{~s}, 1 \mathrm{H}) \mathrm{ppm} ;{ }^{13} \mathrm{C}$ NMR $(125$ MHz, DMSO): $\delta=14.58,17.74,49.99,60.23,70.33$, $100.00,110.57,127.75,127.90,129.33,129.89,131.03$, 133.66, 133.80, 134.42, 138.14, 138.98, 143.48, 143.92, $152.35,160.93$ ppm. $m / z(M S)$ : calcd for $\mathrm{C}_{23} \mathrm{H}_{20} \mathrm{Cl}_{2} \mathrm{~N}_{5} \mathrm{O}_{4}$ $[\mathrm{M}+\mathrm{H}]^{+}$500.09, found 500.10.

1-(2-Methyl-5-nitro-1H-imidazol-1-yl)propan-2-yl-5-(4-i odophenyl)-1-phenyl-1H-pyrazole-3-carboxylate (6bc): yellow solid, mp: $182-183{ }^{\circ} \mathrm{C}$; ${ }^{1} \mathrm{H}$ NMR $(500 \mathrm{MHz}$, DMSO): $\delta=1.44$ (d, $J=6.4 \mathrm{~Hz}, 3 \mathrm{H}), 2.55$ (s, 3H), 4.54 (dd, $J=15.0,9.7 \mathrm{~Hz}, 1 \mathrm{H}), 4.69$ (dd, $J=15.0,2.7 \mathrm{~Hz}, 1 \mathrm{H})$, 5.46 (ddd, $J=9.4,6.4,2.8 \mathrm{~Hz}, 1 \mathrm{H}), 7.02$ (s, H), 7.04 (s, $\mathrm{H}), 7.07$ (s, H), 7.32-7.34 (m, 2H), 7.48-7.49 (m, 2H), $7.73(\mathrm{~d}, J=8.4 \mathrm{~Hz}, 2 \mathrm{H}), 8.02(\mathrm{~s}, 1 \mathrm{H}) \mathrm{ppm} ;{ }^{13} \mathrm{C} \mathrm{NMR}$ (125 MHz, DMSO): $\delta=14.58,17.75,50.01,70.22,96.31$, $100.00,110.23,126.03,128.75,129.39,129.85,131.04$, $133.66,137.95,138.98,139.38,143.25,144.02,152.35$, 161.00. $\mathrm{m} / z$ (MS): calcd for $\mathrm{C}_{23} \mathrm{H}_{21} \mathrm{IN}_{5} \mathrm{O}_{4}[\mathrm{M}+\mathrm{H}]^{+}$558.06, found 558.10 .

1-(2-Methyl-5-nitro-1H-imidazol-1-yl)propan-2-yl-1,5-di phenyl-1H-pyrazole-3-carboxylate (6dc): yellow solid, mp: $183-185{ }^{\circ} \mathrm{C} ;{ }^{1} \mathrm{H}$ NMR (500 MHz, DMSO): $\delta=1.45$ $(\mathrm{d}, J=6.4 \mathrm{~Hz}, 3 \mathrm{H}), 2.56(\mathrm{~s}, 3 \mathrm{H}), 4.54(\mathrm{dd}, J=15.0,9.7$ $\mathrm{Hz}, 1 \mathrm{H}), 4.70(\mathrm{dd}, J=15.0,2.7 \mathrm{~Hz}, 1 \mathrm{H}), 5.46(\mathrm{ddd}, J=$ 9.3, 6.3, $2.8 \mathrm{~Hz}, 1 \mathrm{H}), 7.03(\mathrm{~s}, \mathrm{H}), 7.22-7.27$ (m, 2H), 7.34-7.39 (m, 3H), 7.44-7.51 (s, 3H), 8.02 (s, 1H) ppm; 
${ }^{13} \mathrm{C}$ NMR (125 MHz, DMSO): $\delta=14.59,17.75,50.01$, $70.19,110.05,126.01,129.08,129.13,129.23,129.39$, 129.74, 133.67, 138.96, 139.54, 143.13, 144.93, 152.35, 161.07 ppm. $m / z$ (MS): calcd for $\mathrm{C}_{23} \mathrm{H}_{22} \mathrm{~N}_{5} \mathrm{O}_{4}[\mathrm{M}+\mathrm{H}]^{+}$ 432.17, found 432.20 .

1-(2-Methyl-5-nitro-1H-imidazol-1-yl)propan-2-yl-5-(4methoxyphenyl)-1-phenyl-1H-pyrazole-3- carboxylate (6ec): yellow solid, mp: $218-220{ }^{\circ} \mathrm{C} ;{ }^{1} \mathrm{H}$ NMR (500 MHz, DMSO): $\delta=1.45$ (d, $J=6.1 \mathrm{~Hz}, 3 \mathrm{H}), 2.55$ (s, 3H), 3.75 $(\mathrm{s}, 3 \mathrm{H}), 4.54(\mathrm{dd}, J=14.5,10.0 \mathrm{~Hz}, 1 \mathrm{H}), 4.69(\mathrm{~d}, J=14.5$ $\mathrm{Hz}, 1 \mathrm{H}), 5.45$ (br, $1 \mathrm{H}), 6.97-6.85$ (m, 3H), 7.17 (d, $J=8.4$, $2 \mathrm{H}), 7.32(\mathrm{~d}, J=5.6,2 \mathrm{H}), 7.46(\mathrm{~s}, 3 \mathrm{H}), 8.02(\mathrm{~s}, 1 \mathrm{H}) \mathrm{ppm}$; ${ }^{13} \mathrm{C}$ NMR (125 MHz, DMSO): $\delta=14.58,17.76,50.03$, $55.69,70.11,109.47,114.60,121.49,126.00,129.15$, $129.72,130.49,133.64,138.99,139.72,143.06,144.86$, 152.36, 160.08, 161.15. $\mathrm{m} / \mathrm{z}$ (MS): calcd for $\mathrm{C}_{24} \mathrm{H}_{24} \mathrm{~N}_{5} \mathrm{O}_{5}$ $[\mathrm{M}+\mathrm{H}]^{+} 462.20$, found 462.30 .

1-(2-Methyl-5-nitro-1H-imidazol-1-yl)propan-2-yl-1-phe nyl-5-(m-tolyl)-1H-pyrazole-3-carboxylate (6fc): yellow solid, mp: $158-160{ }^{\circ} \mathrm{C}$; ${ }^{1} \mathrm{H}$ NMR (500 MHz, DMSO): $\delta=$ 1.45 (d, $J=6.4 \mathrm{~Hz}, 3 \mathrm{H}), 2.25$ (s, 3H), 2.55 (s, 3H), 4.54 $(\mathrm{dd}, J=15.0,2.7 \mathrm{~Hz}, 1 \mathrm{H}), 4.70(\mathrm{dd}, J=15.0,2.7 \mathrm{~Hz}, 1 \mathrm{H})$, 5.46 (ddd, $J=9.3,6.4,2.8 \mathrm{~Hz}, 1 \mathrm{H}), 6.96(\mathrm{~m}, J=7.2,1 \mathrm{H})$, $7.01(\mathrm{~s}, \mathrm{H}), 7.14(\mathrm{~s}, \mathrm{H}), 7.18-7.24(\mathrm{~m}, 2 \mathrm{H}), 7.30-7.33(\mathrm{~m}$, 2H), 7.50-7.48 (m, 3H), 8.02 (s, 1H) ppm; ${ }^{13} \mathrm{C}$ NMR $(125$ MHz, DMSO): $\delta=14.60,17.74,50.02,70.22,110.35$, $126.03,128.10,129.21,129.39,129.84,130.91,133.69$, $134.24,139.32,143.18,143.74,161.00 \mathrm{ppm} . \mathrm{m} / z$ (MS): calcd for $\mathrm{C}_{24} \mathrm{H}_{24} \mathrm{~N}_{5} \mathrm{O}_{4}[\mathrm{M}+\mathrm{H}]^{+} 446.18$, found 446.19 .

1-(2-Methyl-5-nitro-1H-imidazol-1-yl)propan-2-yl-5-(3methoxyphenyl)-1-phenyl-1H-pyrazole-3- carboxylate (6gc): yellow solid, mp: $175-176{ }^{\circ} \mathrm{C} ;{ }^{1} \mathrm{H}$ NMR $(500 \mathrm{MHz}$, DMSO): $\delta=1.44(\mathrm{~d}, \mathrm{~J}=6.4 \mathrm{~Hz}, 3 \mathrm{H}), 2.55$ (s, 3H), 3.75 (s, $3 \mathrm{H}), 4.54(\mathrm{dd}, \mathrm{J}=15.0,2.7 \mathrm{~Hz}, 1 \mathrm{H}), 4.69$ (dd, J = 15.0, $2.6 \mathrm{~Hz}, 1 \mathrm{H}), 5.45$ (br, 1H), 6.91-6.95 (m, 3H), 7.17 (d, J = $8.8,2 \mathrm{H}), 7.31-7.33(\mathrm{~m}, 2 \mathrm{H}), 7.45-7.48(\mathrm{~m}, 3 \mathrm{H}), 8.03(\mathrm{~s}$, 1H) ppm; ${ }^{13} \mathrm{C}$ NMR (125 MHz, DMSO): $\delta=14.59,17.75$, $21.34,50.02,70.15,109.96,125.97,126.14,128.93$, $129.15,129.22,129.66,129.70,130.02,133.67,138.46$, $139.59,143.09,145.02,152.35,161.07 \mathrm{ppm} . \mathrm{m} / \mathrm{z}$ (MS): calcd for $\mathrm{C}_{24} \mathrm{H}_{24} \mathrm{~N}_{5} \mathrm{O}_{5}[\mathrm{M}+\mathrm{H}]^{+} 462.18$, found 462.20 .

\section{Author contribution}

Qing-Hu Teng and Gui-Xia Sun: Synthesis and characterization, Shu-Ying Luo: MTT assay, Kai Wang and Fu-Pei Liang: Concept, Writing, Reviewing and Editing.

\section{Acknowledgment}

This work was financially supported by the National Natural Science Foundation of China (Nos. 21961008 and 21771043) and the Guangxi Natural Science Foundation (No. 2018GXNSFAA138123).

\section{Compliance with ethical standards}

Conflict of interest The authors declare that they have no conflict of interest.

Publisher's note Springer Nature remains neutral with regard to jurisdictional claims in published maps and institutional affiliations.

\section{References}

[1] (a) Blakemore DC, Castro L, Churcher I, Rees DC, Thomas AW, Wilson DM, Wood A. Organic synthesis provides opportunities to transform drug discovery. Nat. Chem. 2018; 10: 383-394. Doi: 10.1038/s41557-018-0021-z. b) Eastgate MD, Schmidt MA, Fandrick KR. On the design of complex drug candidate syntheses in the pharmaceutical industry. Nat. Rev. Chem. 2017; 1: 0016. Doi: 10.1038/s41570-017-0016. c) Foley DJ, Nelson A, Marsden SP. Evaluating New Chemistry to Drive Molecular Discovery: Fit for Purpose? Angew. Chem. Int. Ed. 2016; 55: 13650-13657. Doi: 10.1002/anie.201604193. d) Hamid A, Elomri A, Daïch A. Expedious and practical synthesis of the bioactive alkaloids rutaecarpine, euxylophoricine A, deoxyvasicinone and their heterocyclic homologues. Tetrahedron Lett. 2006; 47: 1777-1781. Doi:10.1016/j.tetlet.2006.01.031. e) Wang L-L, Jiang T, Li P-H, Sun R-J, and Zuo Z. Asymmetric Syntheses of Spirooxindole-dihydroquinazolinones by Cyclization Reactions between $N$-substituted Anthranilamides and Isatins. Adv. Synth. Catal. 2018; 360: 4832-4836. Doi: 10.1002/adsc. 201801329 .

[2] a) Deiana V, María G-C, Pazos MR, Javier F-R, Asproni B, Cichero E, et al. Tricyclic pyrazoles. Part 8. Synthesis, biological evaluation and modelling of tricyclic pyrazole carboxamides as potential CB2 receptor ligands with antagonist/inverse agonist properties. Eur. J. Med. Chem. 2016; 112: 66-80. Doi: 10.1016/j.ejmech.2016.02.005. b) Kotsikorou E, Navas F, Roche MJ, Gilliam AF, Thomas BF, Seltzman $\mathrm{HH}$, et al. The Importance of Hydrogen Bonding and Aromatic Stacking to the Affinity and Efficacy of Cannabinoid Receptor CB2 Antagonist, 5-(4-chloro-3-methylphenyl)-1-[(4-methylphenyl)m ethyl]-N-[(1S,2S,4R)-1,3,3-trimethylbicyclo[2.2.1]h ept-2-yl]-1H-pyrazole-3-carboxamide (SR144528). J. Med. Chem. 2013; 56: 6593-6612. Doi: 10.1021/jm400070u. c) Narayanan S, Maitra R, Deschamps JR, Bortoff $\mathrm{K}$, Thomas JB, et al. Discovery of a novel small molecule agonist scaffold for the APJ receptor. Bioorg. Med. Chem. 2016; 24: 3758-377. Doi: 10.1016/j.bmc.2016.06.018.

[3] Wang ZQ, Song T, Feng YG, Guo ZW, Fan YD, Xu WJ, et al. Bcl-2/MDM2 Dual Inhibitors Based on Universal Pyramid-Like $\alpha$-Helical Mimetics. J. Med. 
Chem. 2016; 59: 3152-3162. Doi: 10.1021/acs.jmedchem.5b01913.

[4] a) Ragavan RV, Vijayakumar V, Kumari NS. Synthesis and antimicrobial activities of novel 1,5-diaryl pyrazoles. Eur. J. Med. Chem. 2010; 45: 1173-1180. Doi: 10.1016/j.ejmech.2009.12.042. b) Bildirici I, Şener A, Tozlu İ. Further derivatives of 4-benzoyl-1,5-diphenyl-1H-pyrazole-3-carboxylic acid and their antibacterial activities. Med. Chem. Res. 2007; 16: 418-426. Doi: 10.1007/s00044-007-9082-z. c) Şener IBA, Atalan E, Battal A, Genc H. Synthesis and antibacterial activity of 4-benzoyl-1-(4-carboxy-phenyl)-5phenyl-1H-pyrazole-3-carboxylic acid and derivatives. Med. Chem. Res. 2009; 18: 327-340. Doi: 10.1007/s00044-008-9130-3. d) Chen L-W, Wang P-F, Tang D-J, Tao X-X, Man R-J, Qiu H-Y, et al. Metronidazole containing pyrazole derivatives potently inhibit tyrosyl - tRNA synthetase: design, synthesis, and biological evaluation. Chem. Biol. Drug Des. 2016; 88: 592-598. Doi: 10.1111/cbdd.12793.

[5] a) Samet M, Rahmi K, Tuba I, Ferdag Ç, Ahmet A, Salim O. Synthesis, structure-activity relationships, and in vitro antibacterial and antifungal activity evaluations of novel pyrazole carboxylic and dicarboxylic acid derivatives. Eur. J. Med. Chem. 2014; 78: 86-96. Doi: 10.1016/j.ejmech.2014.03.033.

[6] Eduardo H-V, Rodrigo A-O, Juan JR-E, Samuel E-S, Francisco H-L. Synthesis, hypoglycemic activity and molecular modeling studies of pyrazole-3-carbohydrazides designed by a CoMFA model. Eur. J. Med. Chem. 2013; 69: 10-21. Doi: 10.1016/j.ejmech.2013.07.054. c) Eduardo H-V, Sandybel S-B, J. Juan R-E, Samuel E-S, Francisco $\mathrm{H}-\mathrm{L}$. Synthesis and molecular docking of $\mathrm{N}^{\prime}$ -arylidene-5-(4-chlorophenyl)-1-(3,4-dichlorophenyl )-4-methyl-1H-pyrazole-3-carbohydrazides as novel hypoglycemic and antioxidant dual agents. Bioorg. Med. Chem. 2016; 24: 2298-2306. Doi: 10.1016/j.bmc.2016.04.007.

[7] a) Abdellatif KRA, Chowdhury MA, Dong Y, Knaus EE. Diazen-1-ium-1,2-diolated nitric oxide donor ester prodrugs of 1-(4-methanesulfonylphenyl)5-aryl-1H-pyrazol-3-carboxylic acids: Synthesis, nitric oxide release studies and anti-inflammatory activities. Bioorg. Med. Chem. 2008; 16: 6528-6534. Doi:10.1016/j.bmc.2008.05.028.

[8] Gawad NMA-E, Hassan GS, Georgey HH. Design and synthesis of some pyrazole derivatives of expected anti-inflammatory and analgesic activities. Med. Chem. Res. 2012; 21: 983-994. Doi: 10.1007/s00044-011-9606-4.
[9] Eduardo H-V, Romina C-A, Juan JR-E, Omar NM-C, Francisco H-L, Jose PC et al. 1,5-Diarylpyrazole and vanillin hybrids: Synthesis, biological activity and DFT studies. Eur. J. Med. Chem. 2015; 100: 106-118. Doi: 10.1016/j.ejmech.2015.06.010.

[10] a) Finn J, Mattia K, Morytko M, Ram S, Yang YF, $\mathrm{Wu} \mathrm{XM}$, et al. Discovery of a potent and selective series of pyrazole bacterial methionyl-tRNA synthetase inhibitors. Bioorg. Med. Chem. Lett. 2003; 13: 2231-2234. Doi: 10.1016/S0960894X(03)00298-1. b) Tabrizi MA, Baraldi PG, Ruggiero E, Saponaro G, Baraldi S, Romagnoli R, et al. Pyrazole phenylcyclohexylcarbamates as inhibitors of human fatty acid amide hydrolases (FAAH). Eur. J. Med. Chem. 2015; 97: 289-305. Doi: 10.1016/j.ejmech.2015.04.064. c) Tabrizi MA, Baraldi PG, Baraldi S, Ruggiero E, Stefano LD, Rizzolio F, et al. Discovery of 1,5-Diphenylpyrazole-3-Carboxamide Derivatives as Potent, Reversible, and Selective Monoacylglycerol Lipase (MAGL) Inhibitors. J. Med. Chem. 2018; 61: 1340-1354. Doi: 10.1021/acs.jmedchem.7b01845. d) Frank AO, Feldkamp MD, Kennedy JP, Waterson AG, Pelz NF, Patrone JD, et al. Discovery of a Potent Inhibitor of Replication Protein A Protein-Protein Interactions Using a Fragment-Linking Approach. J. Med. Chem. 2013; 56: 9242-9250. Doi: 10.1021/jm401333u. e) Ahlström MM, Ridderström M, Zamora I, and Luthman K. CYP2C9 Structure-Metabolism Relationships: Optimizing the Metabolic Stability of COX-2 Inhibitors. J. Med. Chem. 2007; 50: 4444-4452. Doi: 10.1021/jm0705096. f) Waterson AG, Kennedy JP, Patrone JD, Pelz NF, Feldkamp M D, Frank AO, et al. Diphenylpyrazoles as Replication Protein A Inhibitors. ACS Med. Chem. Lett. 2015; 6: 140-145. Doi: 10.1021/ml5003629.

[11] Raji I, Yadudu F, Janeira E, Fathi S, Szymczak L, Kornacki JR, et al. Bifunctional conjugates with potent inhibitory activity towards cyclooxygenase and histone deacetylase. Bioorg. Med. Chem. 2017; 25: 1202-1218. Doi: 10.1016/j.bmc.2016.12.032.

[12] a) Shen F-Q, Wan Z-C, Wu S-Y, Ren S-Z, Man R-J, Wang B-Z, et al. Synthesis of novel hybrids of pyrazole and coumarin as dual inhibitors of COX-2 and 5-LOX. Bioorg. Med. Chem. Lett. 2017; 27: 3653-3660. Doi: 10.1016/j.bmcl.2017.07.020. b) Li Z, Wang Z-C, Li X, Abbas M, Wu S-Y, Ren S-Z, et al. Design, synthesis and evaluation of novel diaryl-1,5-diazoles derivatives bearing morpholine as potent dual COX-2/5-LOX inhibitors and antitumor agents. Eur. J. Med. Chem. 2019; 169: 168-184. Doi: 10.1016/j.ejmech.2019.03.008.

[13] a) Nyirjesy P, Schwebke JR. Secnidazole: next-generation antimicrobial agent for bacterial 
vaginosis treatment. Future Microbiol. 2018; 13: 507-524. Doi: 10.2217/fmb-2017-0270. b) Aziz MA AE, Sharifipour F, Abedi P, Jahanfar S, Judge HM. Secnidazole for treatment of bacterial vaginosis: a systematic review. BMC Womens Health. 2019, 1, 121-133. Doi: 10.1186/s12905-019-0822-2.

[14] a) Ang CW, Jarrad AM, Cooper MA, Blaskovich MAT. Nitroimidazoles: Molecular Fireworks That Combat a Broad Spectrum of Infectious Diseases. J. Med. Chem. 2017; 60: 7636-7657. Doi: 10.1021/acs.jmedchem.7b00143. b) Kaiser M, Bray MA, Cal M, Trunz BB, Torreele E, Brun R. Antitrypanosomal Activity of Fexinidazole, a New Oral Nitroimidazole Drug Candidate for Treatment of Sleeping Sickness. Antimicrob. Agents Chemother. 2011; 55: 5602-5608. Doi: 10.1128/AAC.00246-11. c) Kumar S, Saha ST, Gu L, Palma G, Perumal S, Singh-Pillay A, et al. 1H-1,2,3-Triazole Tethered Nitroimidazole-Isatin Conjugates: Synthesis, Docking, and Anti-Proliferative Evaluation against Breast Cancer. ACS Omega 2018; 3: 12106-12113. Doi: 10.1021/acsomega.8b01513. f) Edwards DI. Mechanism of antimicrobial action of metronidazole. J. Antimicrob. Chemother. 1979; 5: 499-502. Doi: 10.1093/jac/5.5.499.

[15] a) Qian Y, Zhang H-J, Zhang H, Xu C, Zhao J, Zhu H-L. Synthesis, molecular modeling, and biological evaluation of cinnamic acid metronidazole ester derivatives as novel anticancer agents. Bioorg. Med. Chem. 2010; 18: 4991-4996. Doi: 10.1016/j.bmc.2010.06.003. b) Lina X, Ruan Q, Zhang XR, Duan XJ, Teng,YG, Zhang JB. 99mTc labelled complexes with secnidazole xanthate: Synthesis and evaluation as potential radiotracers to target tumor hypoxia. Appl. Radiat. Isotopes 2018; 140: 289-293. Doi: 10.1016/j.apradiso.2018.07.036. c) Oliveira APA, Freitas JTJ, Diniz R, Pessoa C, Maranhão SS, Ribeiro JM, E, et al. Triethylphosphinegold(I) Complexes with Secnidazole-Derived Thiosemicarbazones: Cytotoxic Activity against HCT-116 Colorectal Cancer Cells under Hypoxia Conditions. ACS Omega 2020; 5: 2939-2946. Doi: 10.1021/acsomega.9b03778.

[16] Zhu HL, Yan TL, Tao XX, Wang PF, Wang ZC, Li Z. CN 104945386. 2015 September 30.

[17] a) Teng Q-H, Yao Y, Wei W-X, Tang H-T, Li J-R and Pan Y-M. Direct $\mathrm{C}-\mathrm{H}$ sulfenylation of quinoxalinones with thiols under visible-light-induced photocatalyst-free conditions. Green Chem. 2019; 21: 6241-6245. Doi: 10.1039/C9GC03045J. b) Teng Q-H, Peng X-J, Mo $\mathrm{Z}-\mathrm{Y}, \mathrm{Xu} \mathrm{Y}-\mathrm{L}$, Tang $\mathrm{H}-\mathrm{T}$, Pan Y-M, et al. Transition-metal-free $\mathrm{C}-\mathrm{N}$ and $\mathrm{C}-\mathrm{C}$ formation: synthesis of benzo[4,5]imidazo[1,2-a]pyridines and 2-pyridones from ynones. Green Chem. 2018; 20: 2007-2012. Doi: 10.1039/C8GC00069G. c) Teng Q-H, Sun Y, Yao Y, Tang H-T, Li J-R, and Pan Y-M. Metal - and Catalyst - Free Electrochemical Synthesis of Quinazolinones from Alkenes and 2 Aminobenzamides. ChemElectroChem 2019; 6: 3120-3124. Doi: 10.1002/celc.201900682. d) Teng Q-H, Xu Y-L, Liang Y, Wang H-S, Wang Y-C, and Pan Y-M. Transition Metal - Free Synthesis of 3 Alkynylpyrrole - 2 - carboxylates via Michael Addition/Intramolecular Cyclodehydration. Adv. Synth. Catal. 2016; 358: 1897-1902. Doi: 10.1002/adsc. 201501073. 
Figures
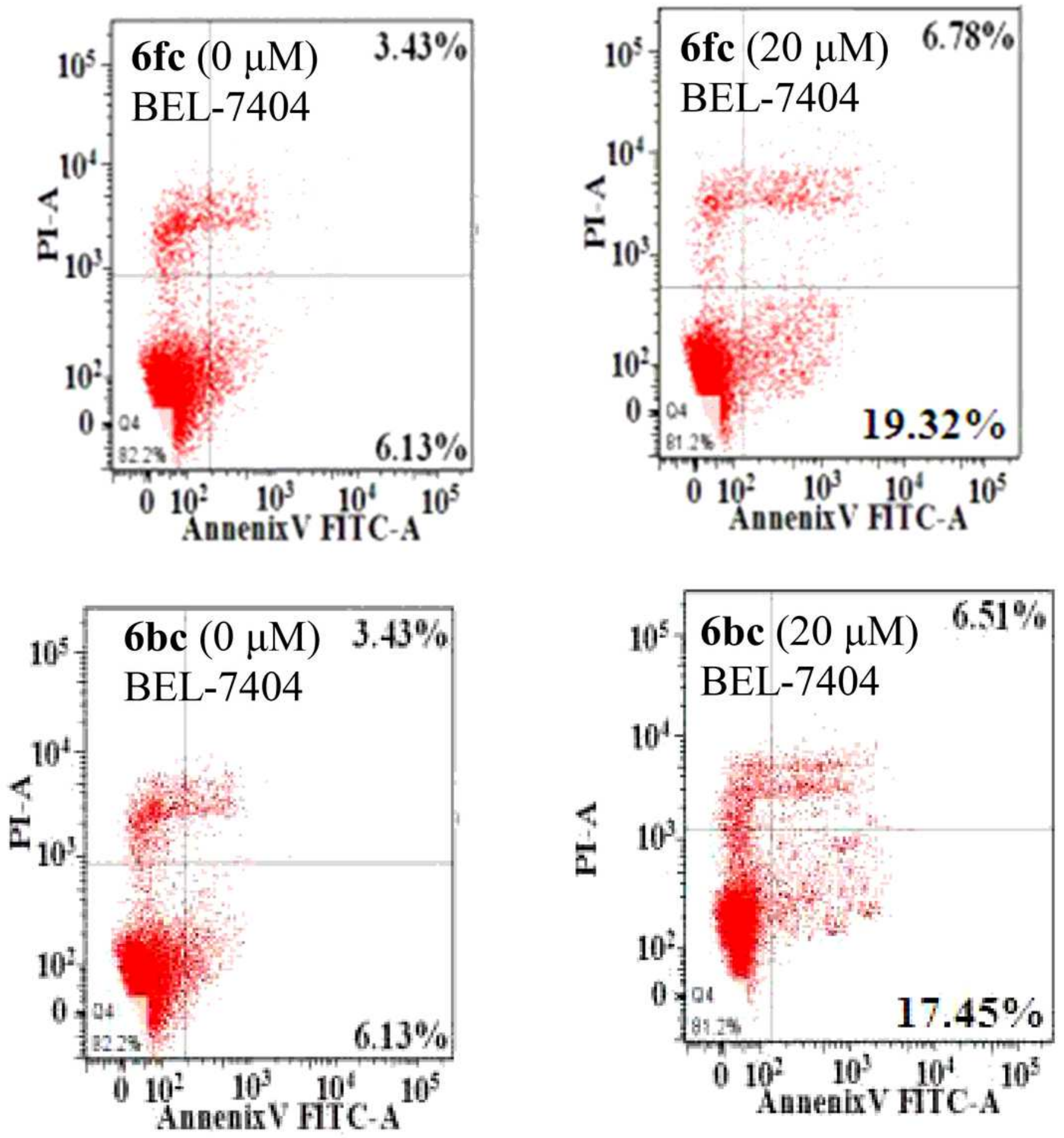

Figure 1

Annexin-V/propidium iodide assay of the BEL-7404 cells treated with $6 \mathrm{fc}$ and $6 \mathrm{bc}(20.0 \mu \mathrm{M})$. 

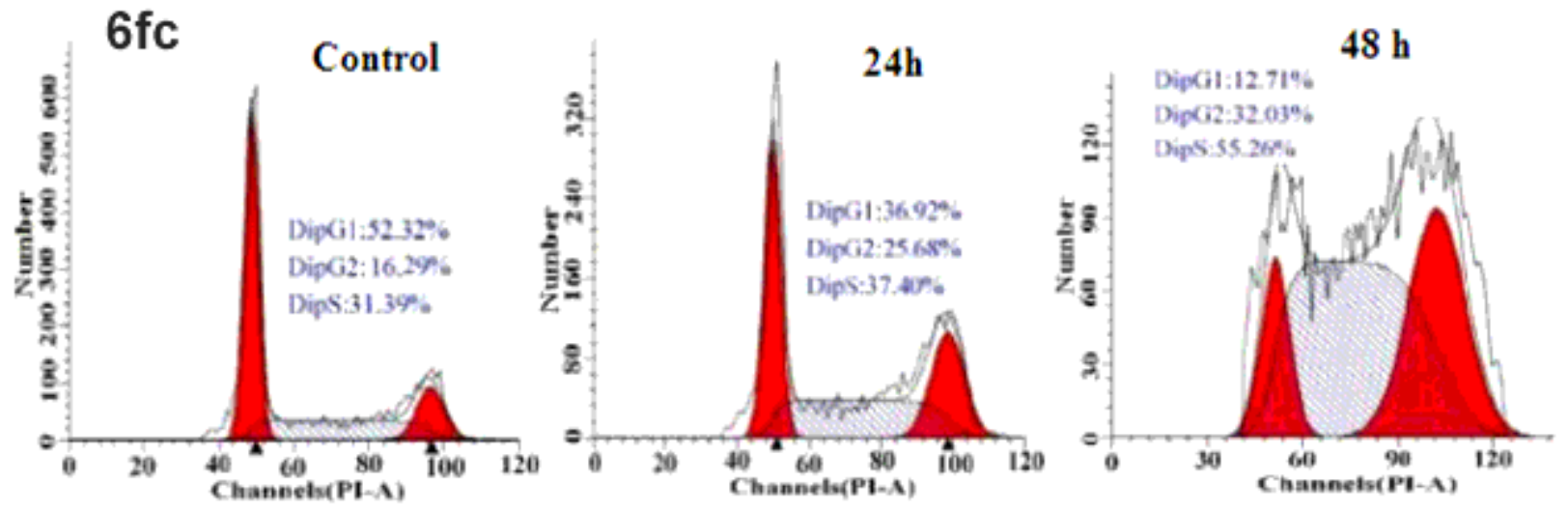

$6 \mathrm{bc}$
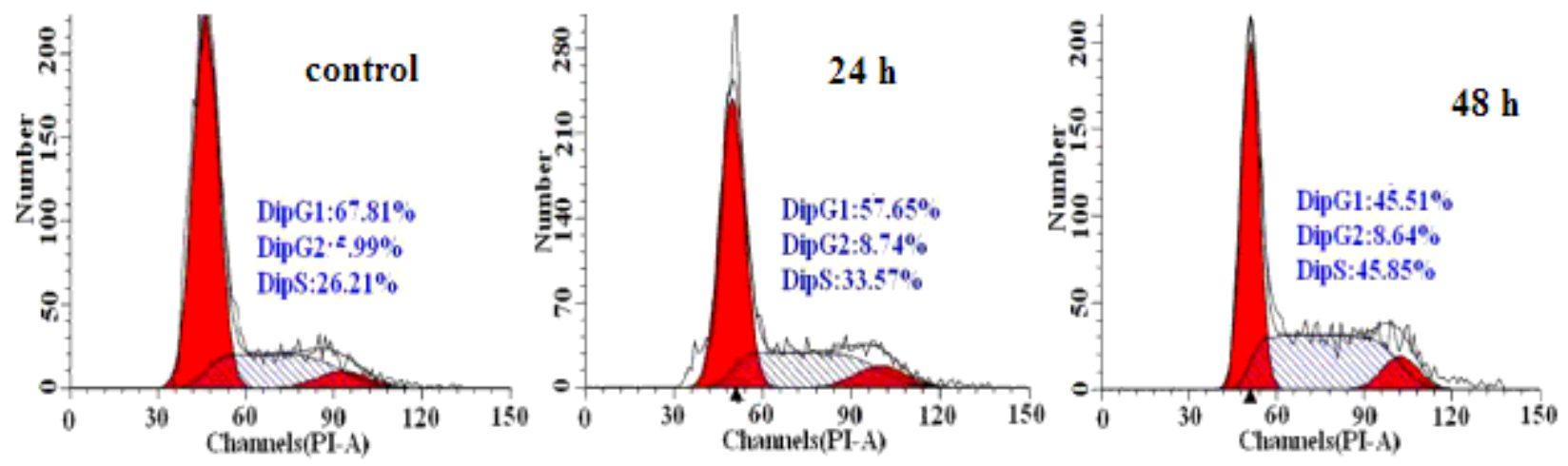

Figure 2

Cell cycle analysis by flow cytometry for BEL-7404 cells treated with $6 \mathrm{fc}$ and $6 \mathrm{bc}$ 


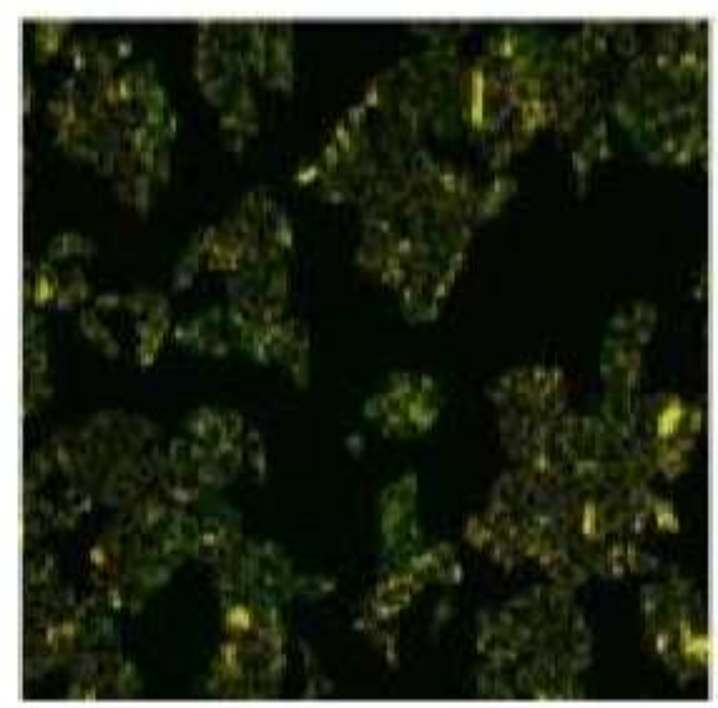

(a) control

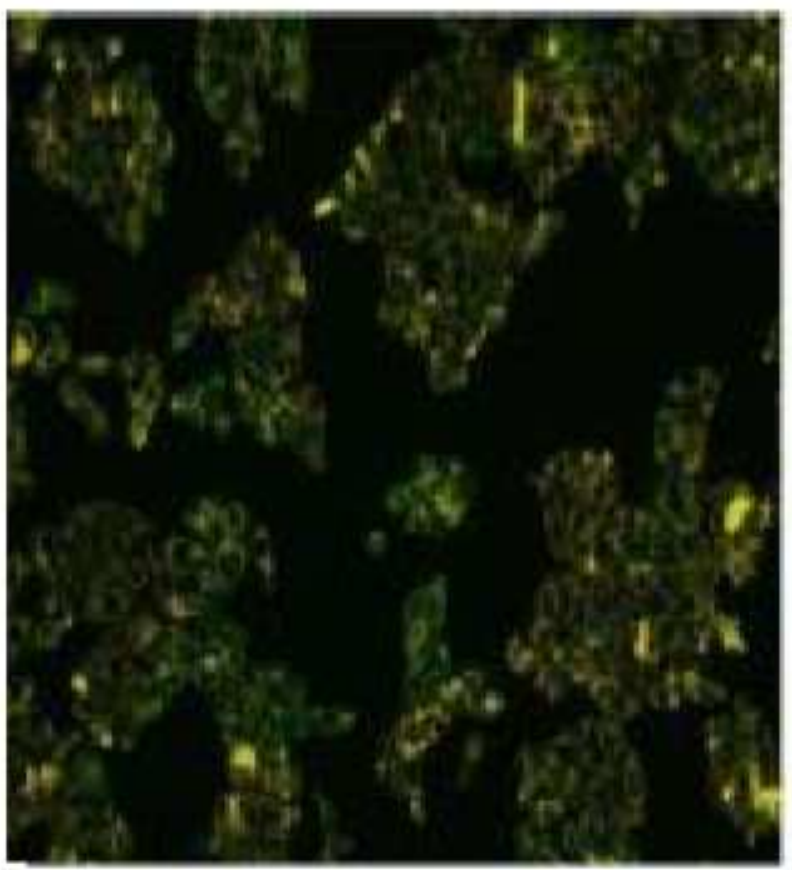

(c) control

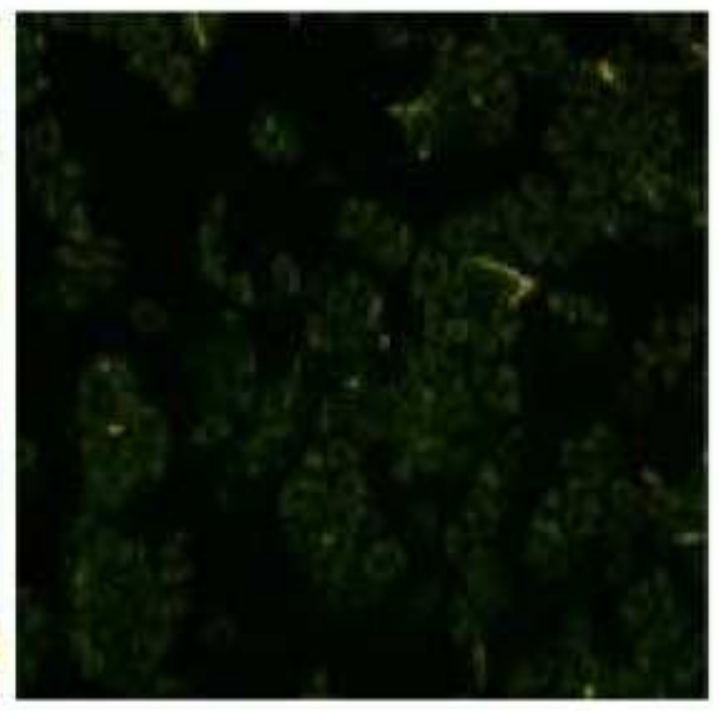

(b) 6 fc $(20 \mu \mathrm{M})$

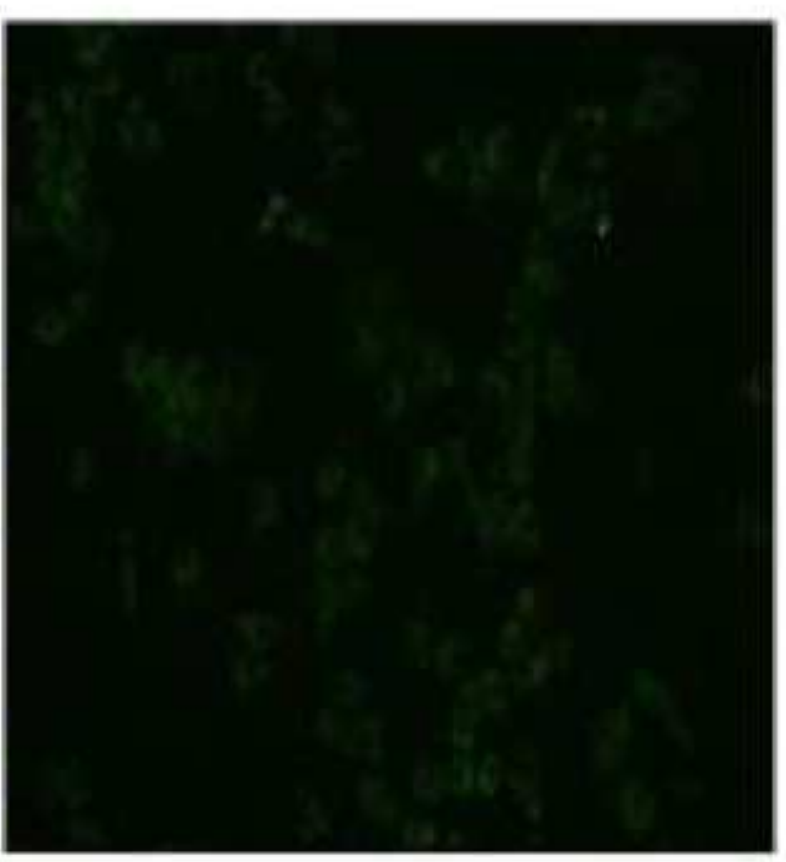

(d) $6 \mathbf{b c}(20 \mu \mathrm{M})$

\section{Figure 3}

Loss of $\Delta \Psi \mathrm{m}$ induced by $6 \mathrm{fc}$ and $6 \mathrm{bc}$.

\section{Supplementary Files}

This is a list of supplementary files associated with this preprint. Click to download. 
- floatimage1.png

- Onlinefloatimage2.png

- Onlinefloatimage3.png 